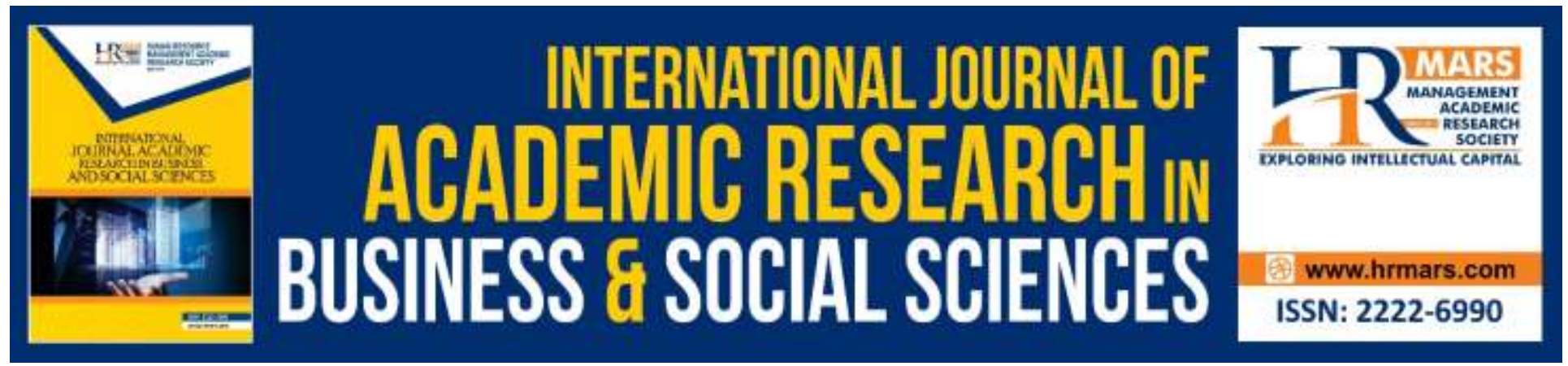

\title{
Understanding the Effectiveness of Blended Learning as a Learning Tool in Tertiary Education in Malaysia
}

Arulanandam Benedict Valentine, Ragunathan Chitra Devi, Selvarajah Prema, Sajnani Sunil Kishor

To Link this Article: http://dx.doi.org/10.6007/IJARBSS/v9-i11/6619

DOI: 10.6007/IJARBSS/v9-i11/6619

Received: 12 October 2019, Revised: 30 October 2019, Accepted: 13 November 2019

Published Online: 28 November 2019

In-Text Citation: (Valentine, Devi, Prema, \& Kishor, 2019)

To Cite this Article: Valentine, A. B., Devi, R. C., Prema, S., Kishor, S. S. (2019). Understanding the Effectiveness of Blended Learning as a Learning Tool in Tertiary Education in Malaysia. International Journal of Academic Research in Business and Social Sciences, 9(11), 942-962.

Copyright: (C) 2019 The Author(s)

Published by Human Resource Management Academic Research Society (www.hrmars.com)

This article is published under the Creative Commons Attribution (CC BY 4.0) license. Anyone may reproduce, distribute, translate and create derivative works of this article (for both commercial and non-commercial purposes), subject to full attribution to the original publication and authors. The full terms of this license may be seen

at: http://creativecommons.org/licences/by/4.0/legalcode

Vol. 9, No. 11, 2019, Pg. 942 - 962

http://hrmars.com/index.php/pages/detail/IJARBSS

JOURNAL HOMEPAGE

Full Terms \& Conditions of access and use can be found at http://hrmars.com/index.php/pages/detail/publication-ethics 


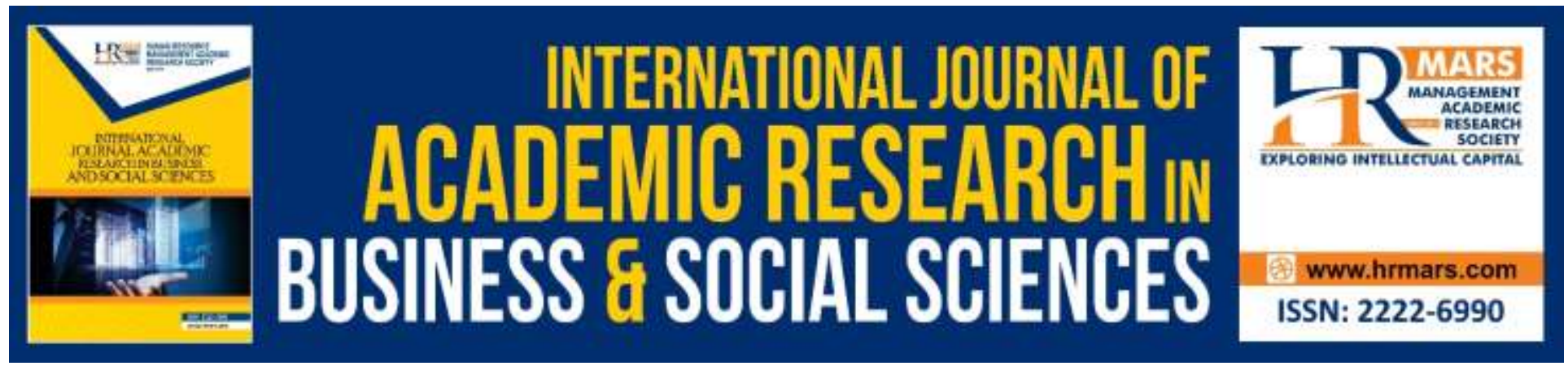

\title{
Understanding the Effectiveness of Blended Learning as a Learning Tool in Tertiary Education in Malaysia
}

\author{
Dr Arulanandam Benedict Valentine \\ Sunway College, Malaysia \\ Email: benedicta@sunway.edu.my \\ Ragunathan Chitra Devi \\ Sunway College, Malaysia \\ Email: chitrad@sunway.edu.my
}

\author{
Selvarajah Prema, Sajnani Sunil Kishor \\ Sunway College, Malaysia \\ Email: premas@sunway.edu.my,sunilk@sunway.edu.my
}

\begin{abstract}
Technology has grown by leaps and bounds, penetrating every stratum of society, industry and government. As much as technology has assisted mankind in her endeavours to progress, it is no doubt that technology has brought "new wine into an old wineskin", bearing fruits of efficiency in every sector of life. Hinssen (2010) expresses well in that, technologies will no longer be termed as technology, but it will find its embrace in daily living with zero tolerance for failure. It is clear that technology is influencing education industry in an unprecedented way. With blendedlearning, technology tools acting as catalyst are inspiring learning and correctly addressing the expectation of people, especially the younger generation.

This study examines the effectiveness of blended learning among five academic programs within Sunway College. This study was motivated by the lack of data on the effectiveness of blended learning at the College level, having implemented it over the last 3 years from the time of this study. An in-depth questionnaire was distributed to a sample size of 745 students (learners) across the 5 programs with the aim to discover the viability of our blended learning, which was implemented over the last three years in the College. Both quantitative and qualitative methods were applied in this study. Blended learning is a learning approach which draws insights from
\end{abstract}


theories linking to behavior and constructivism. This study adopts the social constructivist theory, in which learning experiences and interactions are taken into consideration.

The findings reveal a rich source of information on blended learning in each program and the necessary opportunities for improvements in tandem with the cognitive responses of the current generation in our classrooms.

Keywords: Blended Learning, Instructionist, Facilitator, Heutagogical

\section{Introduction}

As we progress along the second decade of the millennium, educationists are faced with the daunting task on improving learning methods to address the ever-technological savvies of our young generation. Over the years, technology has placed its mark as a catalyst in moulding areas of growth in the education system globally. Malaysia is no exception to this fact. Technology, especially the internet technologies, is found to be one of the fastest growing and extremely penetrative tools in various parts of the economic infrastructures (Li et al, 2014). As such, various pedagogical methods have been introduced with the help of technologies to create an adaptive learning environment for the young generation. One of the ever-increasing pedagogical methods is the introduction of Blended Learning $(\mathrm{BL})$ in the education framework globally, which is clearly visible in tertiary institutions. In the words of Seife (2000), BL is a "dangerous idea" as it challenges the very fundamentals of face-to-face teaching method; it requires adaptation and collaboration of technologies and traditional methods. It also poses a challenge to institutions, requiring them to invest in technologies and trainings to address this new approach. Studies by Garrison and Kanuka (2004), Horton (2000), Owston et al., (2008) and Smyth et al., (2012) embrace the fact that BL has a great advantage, as it is a mix of technologies and traditional approaches. The approach of BL is not to shun traditional teaching methods out of the window, but on the contrary, uses traditional approach alongside online and software applications to aid and enhance learning. Studies by Mayer (2005), stresses that, cognitive theory indicates that technology such as multimedia supports the human brain to receive pictures and motivates interaction among listeners. This is apt in addressing learning challenges among the millennial, cultivating learner-centred orientation. Donnelly, 2010, Sharpe et al, (2006), Wang et al (2009), Woltering et al (2009) and Yen and Lee (2011) concurs that BL is an approach which alters the direction from the teaching focus to learning focus, which positions the students to be responsible in their learning.

According to Sloman (2007), blended learning is an approach where there is a combination of methods of delivery applying technology and traditional methods. In addition, BL addresses the shortcomings of on-line learning or e-learning. Such pedagogical method has seen success in education, from primary to tertiary level. Well, one can only agree that BL has arrived and here for longevity. Such nuances have set the tone for an adaptive liquefied model to withstand the challenges in delivery methodologies. Many scholars maintain the view that technology into education approach is leading the direction in higher education (Arbaugh, 2008; Williams, 2008; Hwang and Francesco, 2010). However, such technology-driven transfer of knowledge would 
place higher demand on larger bandwidth transmissions, which could be one of the obstacles in the implementation of BL methods into classrooms, as it would reflect on high cost of investment. Nevertheless, as Lamont (2016) stresses that there are numerous methods or varying combinations within blended learning which require small or marginal investments. In comparison to the promises of blended learning, such investments would be welcomed, bearing in mind the endless innovation possibilities.

The aim of this paper is to explore the effectiveness of BL from the tertiary students' perspective in Sunway College, Malaysia. BL has been introduced over the last three years, to heed the call of the Malaysian Ministry of Education's Blue Print on Education (2015-2025), to improve learners' quality, delivery and moulding a pertinent generation available for the workforce. The rationale of this study is to address the gap in the discovery of the effectiveness and the perception of tertiary students in the usage of $B L$ in the five programs which are conducted in the College. Such data would be helpful in discovering the effectiveness of BL within these 5 programmes and identifying areas of improvements which are necessary to ensure a proper learning ecosystem. A sample of 745 students across five programs was taken for this study from a population of 6,000 full-time students. This is the first formal study undertaken in the College, across five programs, in which areas of improvements were discovered. In addition, this research provides a platform to gauge whether, the academics are on the "right track" in the application and implementation of $\mathrm{BL}$ in the learning process. This paper is structured; firstly, by addressing the meaning and theories of BL used in this study, the developments in BL, research methodology undertaken in this study, findings and conclusion, limitations and areas for future research.

\section{Literature Review}

\section{Meanings and Theories of BL}

There are numerous definitions of BL. This study defines BL as a combination of technology with face-to-face learning. It does not eradicate face-to-face learning, but complements the traditional approach. Such an approach is in line with the common definitions surrounding BL. Moreover, studies by Bliuc et al (2007), Green et al (2006), Jonas and Burns (2010), Marsh et al (2008), Sharpe et al (2006), and Stacey and Gerbic (2008) agrees in that there is no single definition of $\mathrm{BL}$ and that it is fundamentally a combination of technology with traditional learning approach. As there are many studies which draws its attention to the definition of BL, Table 1 below provides the list of such studies. 
Table 1: BL definitions (Poon, 2014)

\begin{tabular}{|c|c|c|}
\hline Author & Year & Description \\
\hline Driscoll & 2002 & $\begin{array}{l}\text { Posits } 4 \text { different ways BL can be defined; } \\
\text { a) a combination of web-based technologies in achieving } \\
\text { learning outcomes } \\
\text { b) pedagogical combinations } \\
\text { c) Mixing of instructional technological approaches with } \\
\text { traditional face-to-face } \\
\text { d) Mixing instructional technology approaches with work } \\
\text { tasks }\end{array}$ \\
\hline Singh & 2003 & $\begin{array}{l}\mathrm{BL} \text { is a mixture of various delivery methods which } \\
\text { supports students' learning }\end{array}$ \\
\hline Dziuban et al & 2006 & $\begin{array}{l}\text { A combination of technologies within pedagogical } \\
\text { approaches into classroom which considers the social } \\
\text { elements of learning. }\end{array}$ \\
\hline Oliver and Trigwell & 2006 & $\begin{array}{l}\text { Subsequent to Driscoll's (2002) definition, authors } \\
\text { contained BL to three definitions i.e. the mixture of tools } \\
\text { and media in e-learning, mixture of pedagogical } \\
\text { approaches, web-based and traditional learning } \\
\text { integration. }\end{array}$ \\
\hline Graham & 2006 & $\begin{array}{l}\text { Is a synchronous convergence of interaction between } \\
\text { human approach, technology }\end{array}$ \\
\hline Mason and Rennie & 2006 & $\begin{array}{l}\text { Extended the definition from Graham (2006) to include } \\
\text { other technologies and pedagogical approaches }\end{array}$ \\
\hline $\begin{array}{l}\text { Littlejohn and } \\
\text { Pegler }\end{array}$ & 2006 & $\begin{array}{l}\text { Broadens the definition of } \mathrm{BL} \text { with different } \\
\text { recommendations of approaches. }\end{array}$ \\
\hline Collins and Blake & 2007 & $\begin{array}{l}\text { The meaning of } \mathrm{BL} \text { to different communities may have } \\
\text { different meaning. The word blended also means } \\
\text { different mode of learning including technological } \\
\text { approaches, and formal and informal learning. }\end{array}$ \\
\hline $\begin{array}{l}\text { Garrison } \\
\text { Vaughan }\end{array}$ & 2008 & $\begin{array}{l}\text { Is a redesign of learning process, where the traditional } \\
\text { approach is fused with that of technological based. }\end{array}$ \\
\hline Williams et al & 2008 & $\begin{array}{l}\text { Distributive learning is combined with traditional } \\
\text { learning, where distributive learning is based on the } \\
\text { motivation that all stakeholders in the learning system } \\
\text { could share and accommodate various learning } \\
\text { style.(Graham, 2006; Saltzberg and Polyson, 1995) }\end{array}$ \\
\hline
\end{tabular}

From the numerous researches above, it is vivid that the definition of BL revolves around the areas of combination of technology with face-to-face learning, which are the common elements 
underpinning numerous definitions, incorporating a paradigm change (Nunan et al, 2000). However, it is also noted in a study by Picciano (2009) who expands the definition of BL with "Blending with Purpose" incorporating generations, learning technology and styles of learning, spelling out that the social and emotional aspects of students, mirroring the current generations mind set and their versatility in technology applications (Figure 1 below).

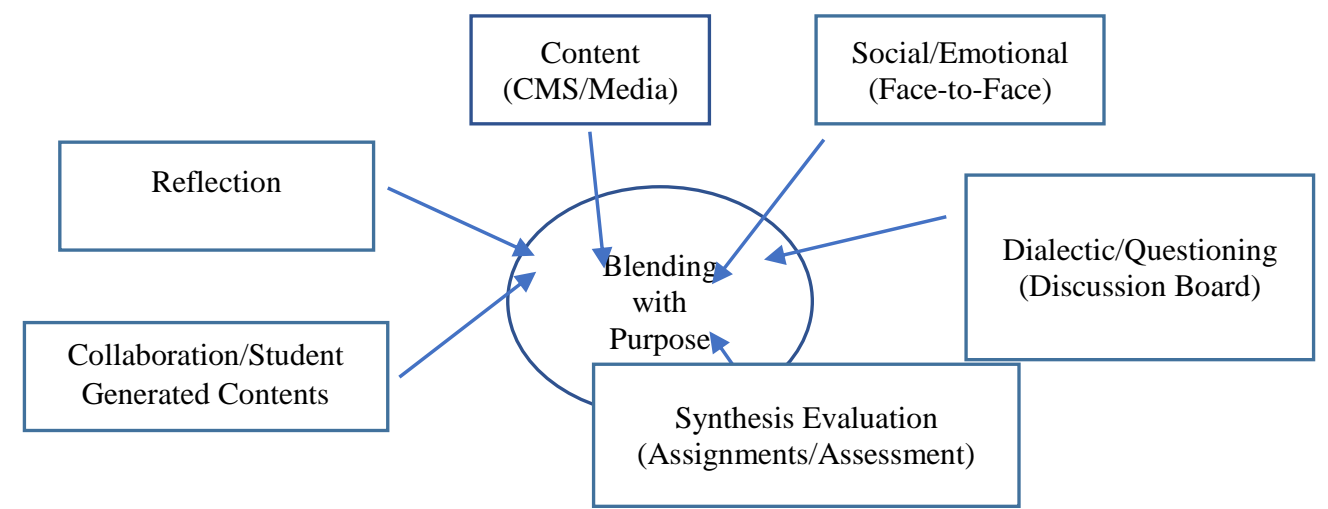

Figure 1: Blending with Purpose (Picciano, 2009)

On the theoretical stance, the theoretical bases for this research are the Social Constructivist Theory (Derry, 1999; McMahon, 1997), Multiple Intelligence Theory (Gardner, 1983), Guided Didactic Conversation (Holmberg, 1983), Three Part Model of Interaction (Moore, 1989) and Interaction Equivalent Theorem (Anderson, 2003). The Social Constructivist Theory highlights three major assumptions, which are, reality stance in which Kukla (2000), point outs that in social constructivism, reality is discovered through social interaction, which depicts our study as BL provides the platform of student-student and student-teacher interactions as it occurs in reality, knowledge , as reflected in the studies by Ernest, 1999, Gredler, 1997 and Prawat \& Floden, 1994, in that knowledge is a human based product and it is designed or constructed based on cultural and social activities or norms, and learning as mentioned by McMahon (1997), in that social constructivist views learning as a social process. He continues to stress that learning is an engagement of societies within and without.

The Multiple Intelligence Theory (Gardner, 1983) which has had an impact on education globally, emphasizes on 8 major intelligences, which are, logical-mathematical, linguistic, visual-spatial, bodily-kinesthetic, musical, interpersonal, intrapersonal, naturalist, have been influencing curriculums, pedagogy and assessment in several ways (Armstrong 2009).The author further elaborates on four key areas involving learning which are critical thinking, creativity, metacognitive skills and social skills. In addition, the Guided Didactic Conversation (Holmberg, 1983) posits that the interaction between teacher-student should be that of a conversational approach and not an instructional approach, in order to overcome psychological and pedagogical separations. The author stresses the need to view learning as a conversation rather than the traditional styles. Moore (1989), takes the queue from Holmberg and extends such a learning 
experience to the 3-Tier approach, i.e. Learner-Content, Learner-Instructor and Learner-Learner. Anderson (2003) introduces an extension from Holmberg and Moore to included not only interactions between Learner-Content, Learner-Instructor and Learner-Learner, but also Content-Content (enhancement of technology). As the generations of learners develop, the technology savvy audience (students) will have a different level of interaction. In addition, studies by Delialoglu and Yildirim (2007), where 25 students were involved in a 14-week study, the findings concur that hybrid learning, such as BL, seemed to be based upon both instructivist and constructivist philosophies, which was found to be valuable to learning.

\section{Phases of Blended Learning}

The BL concept is not an "old" idea. In fact, in a paper by Guzer and Caner (2013) noted that the reason for the introduction of $B L$ originated from the drawbacks faced via pure online pedagogy. Hence, blended approach seemed to arise in the midst of moving away from an entire dependence on online learning. The authors highlighted that there are 3 phases in the development of BL.

First phase (1999-2002)

In this phase researchers were delving on the idea of BL and to enforce deeper understanding of BL. Studies by Cooney et al. (2000) was one of the earliest of such exploration. Voci and Young (2001) made an empirical application of BL into a leadership programme and discovered a greater interaction among participants and improved efficiency. Other empirical studies were Bonk et al (2002), where BL was used in a military curriculum. Even with several studies, there were no conclusive definitions on BL.

Second phase (2003-2006)

In this second phase is where definitions were formulated. Studies by Osguthorpe and Graham (2003), Singh (2003), Garrison and Kanuka (2004) and Graham (2006) are among the most cited studies regarding definition of BL. One commonality in the various definitions is that BL is a combination of technology and traditional approach.

Third phase (2007-2009)

This phase is also known as "popularity" phase (Guzer and Caner, 2014). There were many researches in this phase and pertinent ones' points to the perception and the effectiveness of BL. On the overall basis, BL was found to be positively received and resulting, in most cases, a positive reward. The works of Akkoyunlu and Soylu (2008), Chandra and Fisher (2009), So and Brush (2008), Chen and Jones (2007), Akyuz and Samsa (2009), Hughes (2007), Melton et al (2009) and Woltering et al (2009) mirrors that BL has proven to be an optimistic approach in improving learning styles and applicable to the millennial.

Studies by Alammary et al (2014), stressed on three impact model used by institutions in the implementation of BL. These impact models are; Low-Impact blend, Medium-Impact blend and 
High-Impact blend. As per Figure 2 below, such stages depict the level of BL in the particular institutions. At Sunway College, the BL stage in which the College is currently positioned is at the Medium-Impact Blend level as teachers have designed and developed BL to a certain extent, the College teachers are experienced in traditional teaching methodologies, teachers were sent for trainings to understand blended approaches and our institution has always provided support and is continuing to invest in trainings and blended pedagogies.

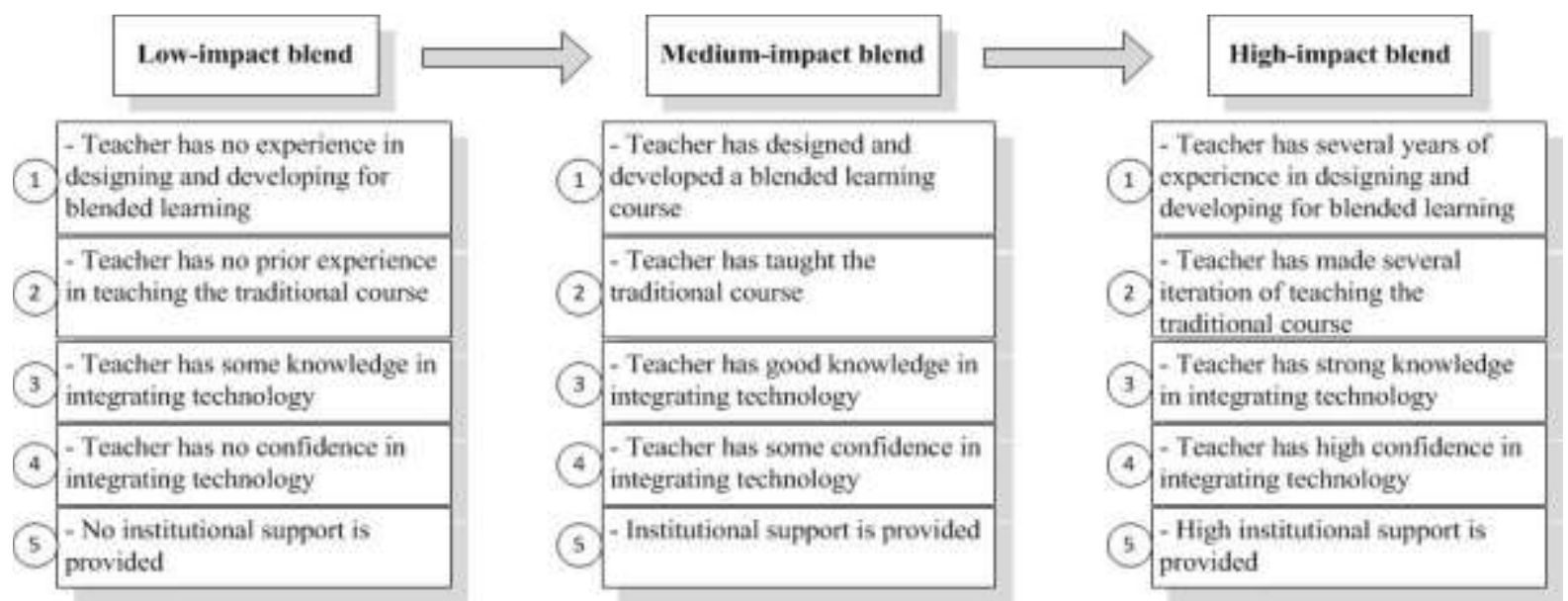

Figure 2: 3-Impact-blend model. Adapted from Alammary.A., Sheard,J., Carbone,A.,(2014). Australasian Journal of Educational Technology, V30(4).

Recently, UNESCO's study on “Blended Learning.... for Quality Higher Education” in collaboration with the Education University of Hong Kong (2017), which involved a selection of Asia Pacific case studies on the implementation of BL (Lim and Wang, 2017) stressed that whilst, BL is an encouraging trend, but the application of such an approach should be custom-made as per the requirements of the subject or program. There no "one-size fits all" approach. The approach should cultivate higher-order thinking skills in tandem with the requirements of the twenty-first century aspirations for higher education institutions. As such BL is an important pedagogy to realise the idea of independent learning or self-directed learning. The report goes on to stress that it is not only the onus of the students to be self-motivated in the learning process, but the role of the teacher takes a shift from that of an instructionist to a facilitator, with constant professional development which would open greater opportunities to improve the delivery of knowledge (Vaughan, 2007). In addition, support from stakeholders such as institutions of higher learning themselves, peer supports and technologists would holistically bring the complete benefit of BL into programs offered. Such a culture would motivate a life-long learning trend (Darling-Hammond and Bransford, 2007), leading towards the incorporation of a heutagogical learning style (Blaschke, 2012, adapted from Hase and Kenyon, 2000). With the speed of the evolution of technology, the future of education seems to be moving in the direction of autonomous and self-determined learning. 


\section{Blended Learning in Malaysian Tertiary Education}

The education system in Malaysia is transforming at a rapid pace. From a colonized education system, prior to World War II, to a much robust and in-trend education system, meeting the needs of all communities, demand and learning styles of the young generation (Grapragasem et al, 2014). The traditional classroom and instructionist approach in many institutions of higher learning are taking a turn in their pedagogical approaches. Technology is used enormously in almost all programmes in institutions of higher learning. The National Higher Education Strategic Plan (NHESP) by the Ministry of Education lays an effective strategic plan to build a sustainable education system, which not only brings relevancy to the workforce but supports the need for lifelong learning with proper infrastructure support (Ministry of Higher Education, 2007). The use of information communication technology (ICT) is in no doubt being a catalyst to spur "education for all". BL currently is applied as part of the learning approaches in institutions of higher learning. Students and staff are being trained in new tools to assist learning and effective delivery. The internet penetration in Malaysia stands at 67\%, which is the seventh highest in Asia, places Malaysia in a pedestal for enormous opportunity in further improving ICT in classroom. In addition, the national e-learning policy (Dasar e-Pembelajaran Negara or DePAN) provide avenues for innovation to thrive in the education arena to spin off democratisation access to learning. Under the National Education Blueprint for Higher Education (2015 - 2025) (Figure 3, below), ten strategies to enhance the education system where technology plays a significant role to mobilize the generations to become a knowledge-driven society and paving the way for a highincome nation. Hence, BL is already in the fore-font of the Malaysian education system.

Sunway College, taking heed from the government, is one of the forerunners among private institutions of higher learning in the implementation BL in programs. Over the last three years both hardware and software investments and trainings were given to teachers in the various tools to usher independent learning among students and to bring relevancy in addressing the learning styles of our young generation. This research is apt in such a time as this, to actually have empirical evidence of the fruits of our labour and to discover areas of improvements in order to effectively address the needs of the ever-evolving current generation of learners. 


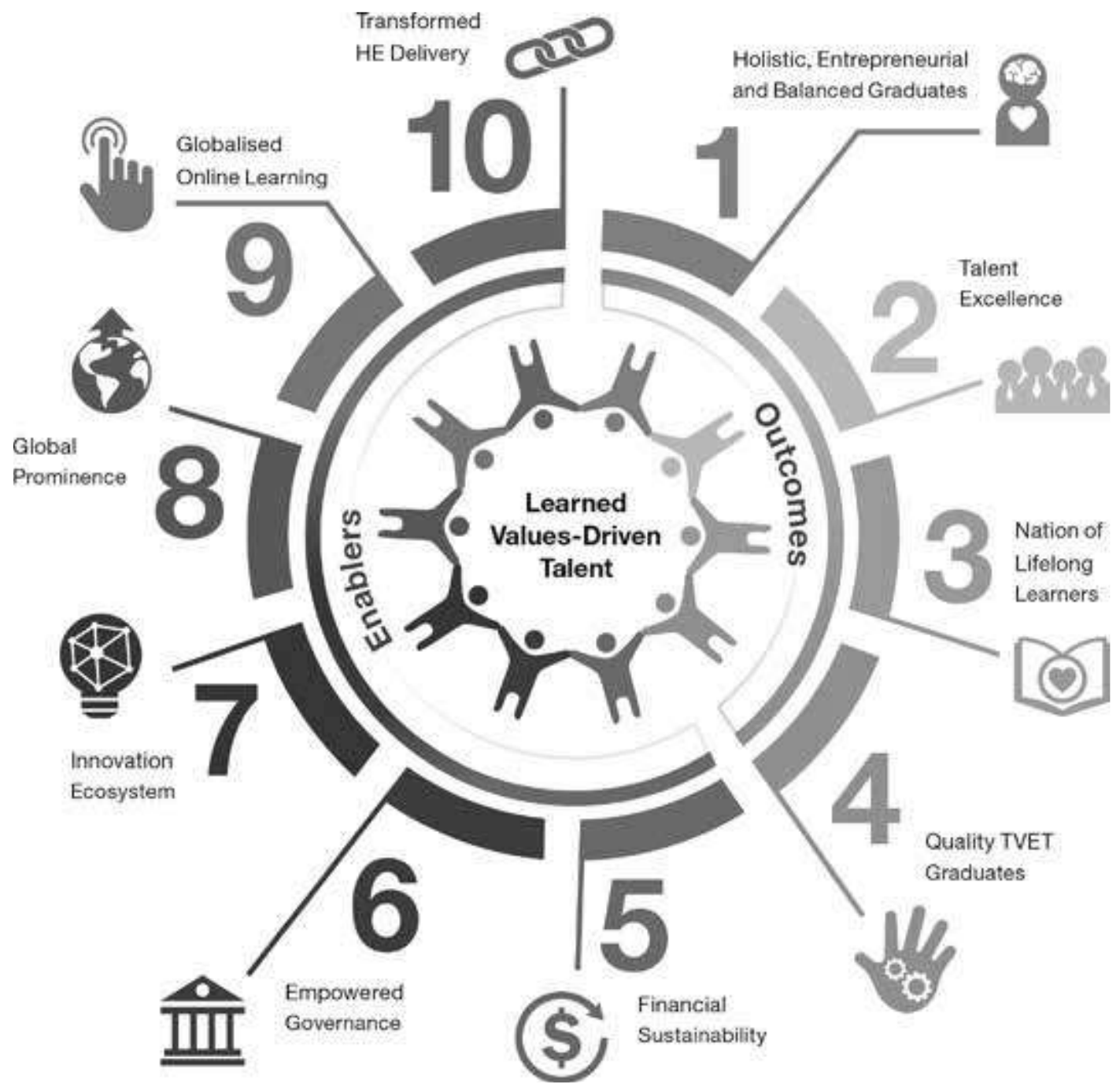

Figure 3: The 10 thrust of the National Education Blueprint for Higher Education. Source: https://www.um.edu.my/docs/default-source/about-um_document/mediacentre/ummagazine/4-executive-summary-pppm-2015-2025.pdf?sfvrsn=4

\section{Methodology}

The methodology adopted in this study is a mixed-method approach with quantitative and qualitative approaches. Questionnaires were distributed to the sample. The questionnaires were structure and closed-end questions. As for qualitative data collection, an interview guide was used. A sample size of 745 was taken from a population size of 6,000 full-time students. The programmes which utilize BL were, the Victoria University Undergraduate Program (VUUP), Foundation in Arts (FIA), Monash University Foundation Year (MUFY), Australian Matriculation (AUSMAT) and Canadian International Matriculation Programme (CIMP). The equal distribution of in-depth survey forms was given in the beginning of 2017. The data collection took about four months to complete as programmes have different administrative structures. The analytical tool 
which was used was SPSS (Version 21). Descriptive and non-parametric test (Spearman's Correlation model) were conducted. The non-parametric test was chosen as the data was found to be non-linear. The qualitative analysis was conducted using coding and thematic approach.

\section{Results}

Using descriptive statistics, the following findings were noted;

Overall satisfaction

It was found that the overall satisfaction recorded was $81.3 \%$. This affirms that more than half of the sample was satisfied with blended learning which had been implemented over the last three years. The program which out shines was AUSMAT, recording $89.9 \%$, with MUFY at $82.3 \%$, VU and CIMP at $82.7 \%$ and FIA at $68.9 \%$. The AUSMAT programme was that, a variety of tools were used which caught the interest of the students as compared to other students.

\section{Usage of BL in Class}

The overall usage of BL was at $84.6 \%$. Once again, the AUSMAT programme recorded the highest percentage at $97.5 \%$, while FIA was at $93.6 \%$, CIMP was at $89.3 \%$, MUFY at $88.7 \%$ and VU recording at $78.3 \%$. Although the usage of $\mathrm{BL}$ in class for FIA was high but they recorded the poorest satisfaction, as above, owing to the usage of the same tool in which the students were feeling bored and unreceptive. As for VU programme, it was found that some of the subjects did not require any blended as they were project based.

\section{Understanding of $B L$}

The overall percentage of understanding were recorded at $78.9 \%$, in which AUSMAT scored the highest at $94.9 \%$, FIA at $87.2 \%$, MUFY at $77.4 \%$, CIMP at $76 \%$ and VU at $74.5 \%$. Upon further analysis, it was found that AUSMAT used a variety of tools and it caused much interaction and deeper understanding of the topic among students. The following Table lists the range of tools used.

Table 2: Lists of BL tools used in each programme (\%)

\begin{tabular}{|l|l|l|l|l|l|l|}
\hline Programme & Video & Padlet & Blendspace & $\begin{array}{l}\text { Flip } \\
\text { Classroom }\end{array}$ & Go Class & Others \\
\hline VU & 64.5 & 10 & 4.3 & 2.6 & 10.2 & 8.4 \\
\hline FIA & 86.2 & 9.2 & 0 & 0 & 3.7 & 0.9 \\
\hline MUFY & 91.9 & 0 & 1.6 & 0 & 3.2 & 3.3 \\
\hline AUSMAT & 48.1 & 32.9 & 1.3 & 16.5 & 0 & 1.2 \\
\hline CIMP & 77.3 & 0 & 4 & 2.7 & 10.7 & 5.3 \\
\hline Total & 69.5 & 10.5 & 3.1 & 3.5 & 7.7 & 5.7 \\
\hline
\end{tabular}

(Others includes: poll everywhere, quizzes, E-Learn (in-house Blackboard))

Other Areas 
$86.7 \%$ of students would like to see more of BL introduced in their subjects, whilst $78.1 \%$ agreed that BL helps in the interaction with teacher on an online basis. Interaction among students was recorded at $83.6 \%$, whilst quality interaction with teachers and students was at $83.5 \%$ and $85.4 \%$ respectively. $94.9 \%$ agreed that technology helps their learning and obtain higher marks. Question on whether BL motivates them to ask questions were at $83.6 \%$, whilst it was agreed at $90.9 \%$ that BL provides the opportunity to reflect what was taught. $87.2 \%$ of the students agreed that BL provided greater opportunity to collaborate and $91.9 \%$ agreed to have a deeper understanding of topics. Owing to the online platform, $96.1 \%$ of the respondents agreed on increased accessibility of information, whilst $87.6 \%$ agreed to have better chances of passing.

In the area of motivation, it was found that $85.4 \%$ were motivated, and $83.9 \%$ of the respondent agreed to have improved time management. With all students possessing their mobile phones, laptops and tabs, $89.7 \%$ of the respondents agreed that their personal devices were a great help as they could access the materials online at anytime, anywhere, with $89.3 \%$ approves of a lighter workload. $77 \%$ of the respondent wanted all their subjects to be blended.

The data was further analysed using SPSS (Version 21) to test for normality, reliability and significance. The Shapiro-Wilk was conducted as the sample size was below 2,000. The data was found to be not linear. Spearman's correlation test was applied, where the correlation of 0.3 and above and the $p$ value of less than 0.05 was found to be significant, especially with reference to technology savvy and experiential learning with BL (Figure 4 and 5, below)

Tests of Normality

\begin{tabular}{|l|c|c|r|r|r|r|}
\hline \multirow{2}{*}{} & \multicolumn{3}{|c|}{ Kolmogorov-Smirnov $^{\text {a }}$} & \multicolumn{3}{c|}{ Shapiro-Wilk } \\
\cline { 2 - 7 } & Statistic & \multicolumn{1}{c|}{$\mathrm{df}$} & \multicolumn{1}{c|}{ Sig. } & Statistic & \multicolumn{1}{c|}{ df } & Sig. \\
\hline Age & .439 & 745 & .000 & .593 & 745 & .000 \\
Nationality & .513 & 745 & .000 & .427 & 745 & .000 \\
Program & .333 & 745 & .000 & .726 & 745 & .000 \\
Gender & .346 & 745 & .000 & .636 & 745 & .000 \\
\hline
\end{tabular}

a. Lilliefors Significance Correction 
INTERNATIONAL JOURNAL OF ACADEMIC RESEARCH IN BUSINESS AND SOCIAL SCIENCES

Vol. 9, No. 11, November, 2019, E-ISSN: 2222-6990 ㄷ 2019 HRMARS

Figure 4: Test of Normality involving 745 samples

\begin{tabular}{|c|c|c|c|c|c|}
\hline \multirow{2}{*}{$\begin{array}{l}\text { Spe } \\
\text { Gender }\end{array}$} & man Correlation & \multicolumn{2}{|c|}{ Program } & \multicolumn{2}{|c|}{ Nationality } \\
\hline & Correlation Coefficient & 1.000 & $-.501^{* *}$ & $.110^{* *}$ & $-.072^{*}$ \\
\hline \multirow[t]{3}{*}{ Program } & Sig. (2-tailed) & . & .000 & .003 & .050 \\
\hline & $\mathrm{N}$ & 745 & 745 & 745 & 745 \\
\hline & Correlation Coefficient & $-.501^{* *}$ & 1.000 & -.003 & .015 \\
\hline \multirow[t]{3}{*}{ Age } & Sig. (2-tailed) & .000 & . & .927 & .689 \\
\hline & $\mathrm{N}$ & 745 & 745 & 745 & 745 \\
\hline & Correlation Coefficient & $.110^{* *}$ & -.003 & 1.000 & -.038 \\
\hline \multirow[t]{3}{*}{ Nationality } & Sig. (2-tailed) & .003 & .927 & . & .304 \\
\hline & $\mathrm{N}$ & 745 & 745 & 745 & 745 \\
\hline & Correlation Coefficient & $-.072^{*}$ & .015 & -.038 & 1.000 \\
\hline \multirow[t]{2}{*}{ Gender } & Sig. (2-tailed) & .050 & .689 & .304 & \\
\hline & $\mathrm{N}$ & 745 & 745 & 745 & 745 \\
\hline
\end{tabular}

Figure 5: Spearman Correlation for 745 sample size. (Correlation of $>0.03$ are Program/Age, Program/Nationality, Program/Gender, Age/Programme, Nationality/Programme, Nationality/Gender, Gender/Programme, Gender/Nationality)

As for the reliability test, Chronbach Alpha was found to be at 0.838 , which signifies that the data set were reliable (Figure 6)

Reliability Statistics

\begin{tabular}{|c|c|c|}
\hline $\begin{array}{c}\text { Cronbach's } \\
\text { Alpha }\end{array}$ & $\begin{array}{c}\text { Cronbach's } \\
\text { Alpha Based } \\
\text { on } \\
\text { Standardized } \\
\text { Items }\end{array}$ & $\mathrm{N}$ of Items \\
\hline .838 & .807 & 26 \\
\hline
\end{tabular}

Figure 6: Reliability Test using Chronbach Alpha

The ANOVA test conducted, was found to be significant (Figure 7) 
ANOVA $^{a}$

\begin{tabular}{|ll|r|r|r|r|c|}
\hline Model & & $\begin{array}{c}\text { Sum of } \\
\text { Squares }\end{array}$ & \multicolumn{1}{c|}{ df } & Mean Square & F & Sig. \\
\hline 1 & Regression & 102.694 & 16 & 6.418 & 3.412 & $.000^{\mathrm{b}}$ \\
& Residual & 1369.467 & 728 & 1.881 & & \\
& Total & 1472.161 & 744 & & & \\
\hline
\end{tabular}

a. Dependent Variable: Program

b. Predictors: (Constant), H11, G1, H1, H10, H3, G5, H9, G4, H8, H4, H2, H6, H5, H7, G2, G3

Figure 7: Anova Test on samples

It was also noted that there was significance in the usage of BL among the pre-university students, in particular males (population size among gender were almost equal), and both males and females were inclined towards technology savvy and experiential learning. Age and nationality have no significance on the programmes, whilst programmes have significance throughout most variables. Spearman's correlation concurs with our earlier descriptive analysis, which shows significance in satisfaction in using $B L$, inclination to videos as a dominant tool in $B L$, weekly usage of tools reveals significance as well and usage of BL in classroom was prominent in pre-university courses.

\section{Qualitative Findings}

Table 3: Summary of qualitative findings on 745 sample size.

\begin{tabular}{|l|l|}
\hline Positive & Negative \\
\hline Unique & Technical glitches \\
\hline Interesting & Sessions are boring \\
\hline Repetitive Learning & No Explanation after BL \\
\hline Improves Understanding & The same tools are Repeated \\
\hline Cognitive Attraction & Class tends to be noisy during BL \\
\hline Improves Accuracy & Encourages laziness \\
\hline Accessibility & Poor Follow Through \\
\hline Time Management & Some Contents are Irrelevant \\
\hline Convenient & \\
\hline
\end{tabular}

The above qualitative findings (Table 3 ), reveal areas of improvements. Whilst the quantitative findings proof that the College is on the right track, the quantitative findings delivers an opportunity for improvements. Hence, as much as BL is encouraging, the teachers in the College has to change their approach from an instructionist to a role of a facilitator, designing blended contents and taking responsibility to ensure knowledge is transferred. Teachers have to ensure that the class is interesting embracing all students of different learning styles. As such, for BL to have a holistic approach, the teachers' role, from the perspective of the students' need consideration. 


\section{Conclusion}

For the College, it is evident that the perception and the effectiveness of the usage of BL among the students (learners) were positive. Due to the Non-Parametric Test, Spearman's correlation was applied, where the correlation of 0.3 and above and the $p$ value of less than 0.05 was found to be significant, especially with reference to technology savviness and experiential learning with BL.

It was also noted that there was significance in the usage of BL among the pre-university students, in particular the males (population size almost equal), both are inclined towards technology savviness and experiential learning. Age and nationality have no significance on the programs, but programs have a significance throughout most variables.

Spearman's correlation concurs with our earlier descriptive analysis reflected in the earlier slides which shows significance in satisfaction in using BL, inclination to videos as a dominant tool in $B L$, weekly usage of tools reveals significance as well, usage of BL in classroom was prominent in preuniversity courses. Hence, such pedagogical approach should continue as an effective knowledge transfer mechanism. The findings at this point concurs with other studies such as Garrison and Kanuka (2004), Horton (2000), Owston et al., (2008) and Smyth et al., (2012). However, this study also brought forth an opportunity for improvement. The qualitative findings were useful as a means to further understand the learning patterns of the College students. These young generation pointed out the areas for improvement as noted above. Students need to be nurtured as to the use of BL so as to instil confidence whilst using BL tools (Yildirim, 2005).

We conclude that the role of the teacher is empirically shifting in the College. Hence, the proposed approach (Figure 8) may find relevance in the continuance of BL usage at the College level in order to have an optimized or holistic learning. The role of a teacher is changing from a traditional style to a facilitator position, where they are content curators, taking responsibility of contents and effective delivery, with improved knowledge in technology usage and highly interactive (engaging). The students, on the other hand, is no longer a recipient of knowledge but takes ownership, self-discipline, interactive and engaging in independent learning. 


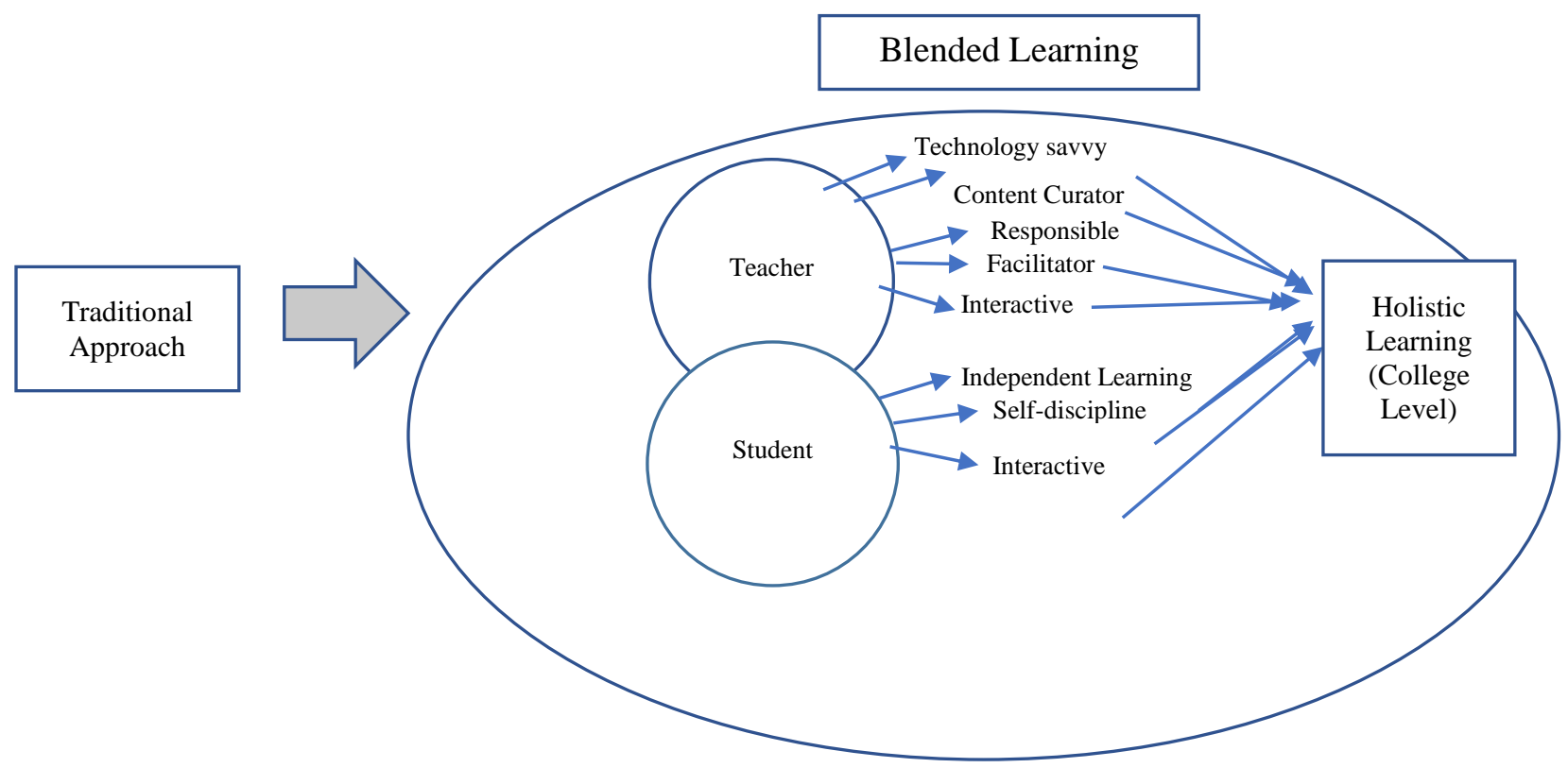

Figure 8: Approach towards Holistic Learning

\section{Limitations and Future Research}

This study was also faced with limitations. The irregularity of class timings across the program was found to be disturbing and we had to ensure that the survey has been appropriately distributed and collected adhering to protocols. It has to be noted that the authors found that the cooperation received from all programs in this survey was positively remarkable. We appreciate both the teachers and students' availability to participate in this survey.

For future research in this area, the sample size could be broadened across the Education Group and similarly, the study could be done across private and public institutions of higher learning, and involving different batches of learners. Such pedagogical approaches have to evolve, as we are faced with a technology-friendly generation who are so engrossed in technological tools. Similar research has to continue for, not only to improve pedagogical approaches, but for learning to be effectively disseminated to the young generation. Future research can be extended to involve perspective of teachers and to discover areas of improvements therein.

\section{Acknowledgement}

The authors would like to acknowledge the cooperation of AUSMAT, MUFY, CIMP, FIA and VU Departments of Sunway College in data collection, with appreciation.

This paper was presented in its originality with the heading "Is Hybrid-Learning Viable as a Learning Tool - The Malaysian Tertiary Education Experience." at the International Conference on Global Education and E-Learning 2017, 10th -11th October 2017, Colombo, Sri Lanka. 


\section{References}

Akkoyunlu, B., \& Soylu, M. Y. (2008). A study of student's perceptions in a blended learning environment based on different learning styles. Educational Technology \& Society, 11(1), 183-193.

Akyüz, H. I., \& Samsa, S. (2009). The effects of blended learning environment on the critical thinking skills of students. Procedia Social and Behavioral Sciences, 1(1), 1744-1748.

Alammary, A., Sheard, J., \& Carbone, A. (2014). Blended learning in higher education: Three different design approaches. Australasian Journal of Educational Technology, 30(4), 440-454.

Anderson, T. (2003a). Getting the mix right again: An updated and theoretical rationale for interaction. International Review of Research in Open and Distance Learning, 4(2).

Anderson, T. (2003b). Modes of interaction in distance education: Recent developments and research questions. In D. M. Moore (Ed.), Handbook of Distance Education (pp. 129144).

Anderson, T. (2008).The theory and practice of online learning . (2nd ed.). Athabasca University Press.

Arbaugh, J. (2008). "Introduction: blended learning: research and practice", Academy of Management Learning \& Education, Vol 7. No 1, pp 130-131.

Armstrong, T. (2009). Multiple Intelligence in Classroom. $3^{\text {rd }}$ Edition. ASCD Publications, USA.

Blaschke, L. M. (2012). Heutagogy and Lifelong Learning: A Review of Heutagogical Practice and Self-Determined Learning. The International Review of Research in Open and Distributed Learning. Vol 13, No 1. http://www.irrodl.org/index.php/irrodl/article/view/1076/2087.

Bliuc, A., Goodyear, P., \& Ellis, R. (2007). Research focus and methodological choices in studies Into students' experiences of blended learning. Internet and Higher Education, 10, 231-244.

Bonk, C. J., Olson, T. M., Wisher, R. A., \& Orvis, K. L. (2002). Learning from focus groups: An examination of blended learning. Journal of Distance Education, 17(3), 97-118.

Bransford, J. (2007). Preparing People for Rapidly Changing Environments. Journal of Engineering Education, January 2007

Chandra, V., \& Fisher, D. L. (2009). Students' perceptions of a blended web-based learning environment. Learning Environment Research, 12,31-44.

Chen, C. C., \& Jones, K. T. (2007). Blended learning vs. traditional classroom settings: Assessing effectiveness and student perceptions in an MBA accounting course. The Journal of Educators Online, 4(1), 1-15.

Collins, K., and Blake, R. M. (2007), "Blended learning: embracing individualism", Chief Learning Officer, Vol. 6 No. 2, pp. 32-37.

Cooney, M. H., Gupton, P., \&O'Laughlin, M. (2000). Blurring the lines of play and work to create blended classroom learning experiences. Early Childhood Education Journal, 27(3), 165-171.

Darling-Hammond, L., \&Bransford, J. (Eds.). (2007). Preparing teachers for a changing world: 
What teachers should learn and be able to do. San Francisco, CA. Wiley Publications. Deliagaoglu, O., \&Yildirim, Z. (2007). Students' Perceptions on Effective Dimensions of Interactive Learning in a Blended Learning Environment. Educational Technology \& Society, 10 (2), 133-146.

Deliagaoglu, O., \&Yildirim, Z. (2008). Design and development of a technology enhanced hybrid instruction based on MOLTA model: Its effectiveness in comparison to traditional instruction. Computers \& Education, 51(1), 474-483.

Derry, S. J. (1999). A Fish called peer learning: Searching for common themes. In A. M. O'Donnell \& A. King (Eds.).

Donnely, R. (2010). Harmonizing technology with interaction in blended problem-based learning. Computers \& Education, 54(2), 350-359.

Driscoll, M. (2002), "Blended learning: let's get beyond the hype", E-Learning, Vol 3 No. 3, p. 1-3.

Dziuban, C., Hartman, J., Juge, F., Moskal, P., and Sorg, S. (2006), "Blended learning enters the mainstream", in Bonk, C.J. and Graham, C.R. (Eds), The Handbook of Blended Learning: Global Perspectives, Local Designs, Pfeiffer, San Francisco, CA, pp. 195-206.

Ernest, P. (1999). Social Constructivism as a Philosophy of Mathematics: Radical Constructivism. (http://www.univie.ac.at/constructivism.EvG/. State University of New York Press.

Gardner, H. (1983). Frames of Mind. New York: Basic Book Inc.

Garrison, D. R., \& Kanuka, H. (2004). Blended learning: Uncovering its transformative potential in higher education. Internet and Higher Education, 7(2), 95-105.

Garrison, D., Vaughan, N. (2008). Blended Learning in Higher Education. SanFrancisco, CA: Jossey-Bass, 2008.

Graham, C. R. (2006). Blended learning systems: Definitions, current trends and future directions. In C. J. Bonk, \& C. R. Graham (Eds.), The Handbook of blended learning: Global perspectives, local designs (pp. 3-21). San Francisco.

Grapragasem, S., Krishnan, A., Mansor, A. N. (2014). Current Trends in Malaysian Higher Education and the Effect on Education Policy and Practice: An Overview. International Journal of Higher Education. Vol 3, No.1.

Gredler, M. E. (1997). Learning and instruction: Theory into practice (3rd ed). Upper Saddle River, NJ: Prentice-Hall.

Green, S. M., Weaver, M., Voegeli, D., Fitzsimmons, D., Knowles, J., Harrison, M. and Shephard, K. (2006), "The development and evaluation of the use of a virtual learning Environment (Blackboard 5) to support the learning of pre-qualifying nursing students Undertaking a human anatomy and physiology module", Nurse Education Today, Vol. 26 No. 5, pp. 388-395.

Guzer, B., Caner, H., (2014). The past, present and future of blended learning; an in depth Analysis of literature. $5^{\text {th }}$ World Conference on Educational Sciences - WCES 2013. Procedia Social and Behavioral Sciences 116 92014) 4596-4603. ScienceDirect.

Hase, S. (2009). Heutagogy and e-learning in the workplace: Some challenges and 
Opportunities. Impact: Journal of Applied Research in Workplace E-learning, 1(1), 4352.

Hase, S., \& Kenyon, C. (2000). From andragogy to heutagogy. In UltiBase Articles. Hinssen, P. (2010). The New Normal. MachMedia, Edison. NJ

Holmberg, B. (1983). Distance education as an academic discipline. ICDE Bulletin, 2, 50-53. Horton, W. (2000). Designing web-based training, J Wiley, USA.

Hughes, G. (2007). Using blended learning to increase learner support and improve retention. Teaching in Higher Education, 12(3), 349-363.

Hwang, A., and Francesco, A.M. (2010). "The influence of individualism-collectivism and power distance on use of feedback channels and consequences of learning". Academy of Management Learning \& Education, Vol 9, No2, pp 243-257.

Jonas, D., \& Burns, B. (2010). The transition to blended e-learning. Changing the focus of Educational delivery in children's pain management. Nurse Education in Practice 10(1), 1-7.

Kukla, A. (2000). Social Constructivism and the Philosophy of Science. New York: Routledge

Lamont, M. (2016). "Blended Synchronous Learning: Reflections from a postgraduate Tourism And Hospitality research methods unit". Conference Proceedings. Southern Cross University, Australia.

Li, K. C., Wong, T. L., Cheung, S. K. S., Lam, J. Ng, K. K. (Eds), (2014). Technology in Education. Transforming Educational Practices with Technology. Conference Proceedings International Conference, ICTE 2014, Hong Kong, China. July 2-4, 2014

Littlejohn, A., \& Pegler, C. (2007). Preparing for Blended e-Learning. London: Routledge

Marsh, D., Pountney, R., and Prigg, R. (2008), C-SAP Scoping Survey on the Use of E-Learning in the Social Sciences, Higher Education Academy: Sociology, Anthropology and Politics, York.

Mason, R., \& Rennie, F. (2006). Elearning: The key concepts. London: Routledge

Mayer, R. E., (2005a). Cognitive theory of multimedia learning. In R.E, Mayer (Ed), The Cambridge Handbook of Multimedia Learning. New York: Cambridge University Press.

McMahon, M. (1997, December). Social Constructivism and the World Wide Web - A Paradigm for Learning. Paper presented at the ASCILITE conference. Perth, Australia.

Melton, B., Graf, J., \& Chopak-Foss, J. (2009). Achievement and satisfaction in blended learning versus traditional general health course designs. International Journal for the Scholarship of Teaching and Learning, 3(1).

Ministry of Education. (2012). Malaysian Education Blueprint 2013-2025. Ministry of Education Malaysia

Ministry of Education, (2015). National Education Blueprint for Higher Education (2015). The 10 thrust of the Malaysian National Education Blueprint for Higher Education. https://www.um.edu.my/docs/default-source/about-um_document/mediacentre/ummagazine/4-executive-summary-pppm-2015-2025.pdf?sfvrsn=4.

Ministry of Higher Education. (2007). National Higher Education Action Plan 2007-2010: Triggering higher education transformation. 
Ministry of Higher Education. (2009). Malaysian Education: Malaysia Centre of Educational Excellence.

Moore, M. G. (1989). Three Types of Interaction. The American Journal of Distance Education. Vol 3, No 2.

Nunan, T., George, R., and McCausland, H. (2000), "Rethinking the ways in which teaching and learning is supported: the flexible centre at the University of South Australia", Journal of Higher Education Policy and Management, Vol. 22 No. 1, pp. 85-98.

Oliver, M., and Trigwell, K. (2005). Can 'blended learning' be redeemed? E-learning 2(1), 1726.

Osguthorpe, R. E., Graham, C. R. (2003). Blended learning environments. Definitions and directions. The Quarterly Review of Distance Education, 4(3), 227-233.

Owston, R., Wideman, H., Murphy, J., and Lupsheyuk, D. (2008), "Blended teacher professional development: a synthesis of three program evaluations", Internet and Higher Education, Vol. 11, pp. 201-210.

Picciano, A. G. (2009). Blending With Purpose: The Multimodal Model. Journal of Asynchronous Learning Networks. Volume 13: Issue 1.

Poon, J. (2013). Blended Learning: An Institutional Approach for Enhancing Students' Learning Experiences. MERLOT Journal of Online Learning and Teaching. Vol 9, No 2.

Prawat, R. S., \&Floden, R. E. (1994). Philosophical Perspectives on Constructivist Views of Learning. Educational Psychologist, 29(1), 37-48.

Saltzberg, S., \& Polyson, S. (1995). Distributed learning on the World Wide Web. Syllabus, 9(1), 10.

Seife, C. (2000). Zero: The biography of a dangerous idea. New York, NY: Penguin Books

Sharpe, R., Benfield, G., Roberts, G., \& Francis, R. (2006). The undergraduate experience of blended learning: A review of UK literature and practice. Retrieved from http://www.heacademy.ac.uk/projects/detail/Ir_2006_sharpe. Quoted in Proceedings ASCILITE, 2008 Melbourne by Stacey. Success Factors for Blended Learning. Elizabeth and Gerbic, Philippa.

Singh, H. (2003). Building Effective Blended Learning Programs. Issue of Educational Technology, Volume 43, Number 6, Pages 51-54.

Sloman, M. (2007). "Making sense of blended learning". Industrial and Commercial Training, Vol 39, No. 6 (315-318).

Smyth, S., Houghton, C., Cooney, A., \& Casey, D. (2012). Students' experiences of blended learning across a range of postgraduate programmes. Nurse education today, 32(4), 464-468.

So, H. J., Brush, T. A. (2008). Student perceptions of collaborative learning, social presence and satisfaction in a blended learning environment: Relationships and critical factors. Elsevier - Computers \& Education 51. pg 318-336.

UNESCO, Sustainable Development Goals, (2017). Blended Learning for Quality Higher Education. Selected Case Studies on Implementation from Asia Pacific. Co-Editors: Lim, C.P., Wang, L. Published by United Nations Educational, Scientific and Cultural 
Organization, Paris, France.

Vaughan, N. (2007). Perspectives on blended learning in higher education. International Journal on ELearning, 6(1), 81-94.

Voci, E., \& Young, K. (2001). Blended learning working in a leadership development programme. Industrial and Commercial Training, 33(5),157-160.

Wang, Q., Zhu, Z., Chen, L. \& Yan, H. (2009). E-Learning in China. Campus-Wide Information Systems, 26, 47-61.

Williams, J. K. (2008). "The handbook of blended learning: global perspective". Academy Management Learning \& Education, Vol 7, No1, pp 132-137.

Woltering, V., Herrler, A., Spitzer, K., Spreckelsen C. (2009). Blended learning positively affects students' satisfaction and the role of the tutor in the problem-based learning process: Results of a mixed-method evaluation. Advances in Health Sciences Education, 14(5), 725-738.

Yen, J. C., \& Lee, C. Y. (2011). Exploring problem solving patterns and their impact on learning achievement in a blended learning environment. Computers \& Education, 56(1), 138145.

Yildirim, Z. (2005). Effect of technology competencies and online readiness on preservice teachers' use of online learning management system, retrieved May 15, 2007, from http://www.leeds.ac.uk/educol. 